\title{
POWER GENERATION INVESTMENT PLANNING \\ IN A MODERN POWER SYSTEM WITH HIGH SHARE OF RENEWABLES
}

\author{
I. Oleinikova ${ }^{1}$, O. Ruksans ${ }^{2}$, M. Turcik ${ }^{3}$, \\ ${ }^{1}$ Institute of Physical Energetics, \\ 21 Aizkraukles Str., Riga, LV-1006, LATVIA \\ ${ }^{2}$ Latvenergo, LATVIA, \\ ${ }^{3}$ SEPS, a.s., SLOVAKIA \\ e-mail: irina@edi.lv
}

\begin{abstract}
This article is focused on investment planning in power generation industry, which becomes an important direction of research under the conditions of newly formed environment of electricity market. The authors emphasize the key role of effective instruments and methods for estimation of the costs and economic efficiency of a generating capacity and its adequacy in a modern power system. In the paper, cost-based concepts are analyzed which form a basis for decision-making and long-term planning of investments in the power generation sector for a power system with high share of renewable energy sources.
\end{abstract} market.

Keywords: power generation, investment planning, electricity

\section{INTRODUCTION}

All the EU countries have targets set on renewable energy sources (RESs) and carbon emissions, each of them facing the same challenge. The actuality of the research is determined by functioning of a power system (PS) as a whole and can be outlined as follows [1-3].

> In recent years the impact of RES deployment on electricity market has becoming ever stronger. The RES-based plants can generate electricity at low short-run marginal costs thus decreasing utilization of conventional power plants when the merit order rule is applied. The short-run marginal cost of power generated from RES is often near zero. This situation is in contrast to conventional power systems for which there are always significant costs for fuel to generate power; furthermore, pricing itself relies upon fundamentally different principles. In the current marginal cost-based pricing environment the responsive loads, storage, and renewables will likely be "price takers" as long as conventional units are on the margin.

The necessity to ensure flexibility and adequacy of a production capacity in the electricity market as well as priority of RES and distributed generation provides incentives for development of new investment planning mechanisms. To 
secure the production capacity adequacy and the reliability of a PS with high RES penetration the effective instrument is needed for its long-term design and optimization based on real characteristics. Therefore, relevant calculations of the system's technical, economic and ecological criteria should be performed.

\section{GENERATING CAPACITY ESTIMATION}

The total Net Generating Capacity (NGC) for the European Network of Transmission System Operators for Electricity (ENTSO-E) as a whole is rapidly increasing. These are also based on the RES development and climate change policy targets. The NGC of nuclear and non-renewable hydro-power (pure pumped storage) plants has slightly increased over the whole forecasted period, whereas the NGC of fossil fuel power plants is expected to decrease (Fig. 1). Within the total RES capacity mix, the wind, solar and biomass power plants fill an increasing share of the overall capacity, while the share of renewable hydro-power plants will most probably decrease [1].

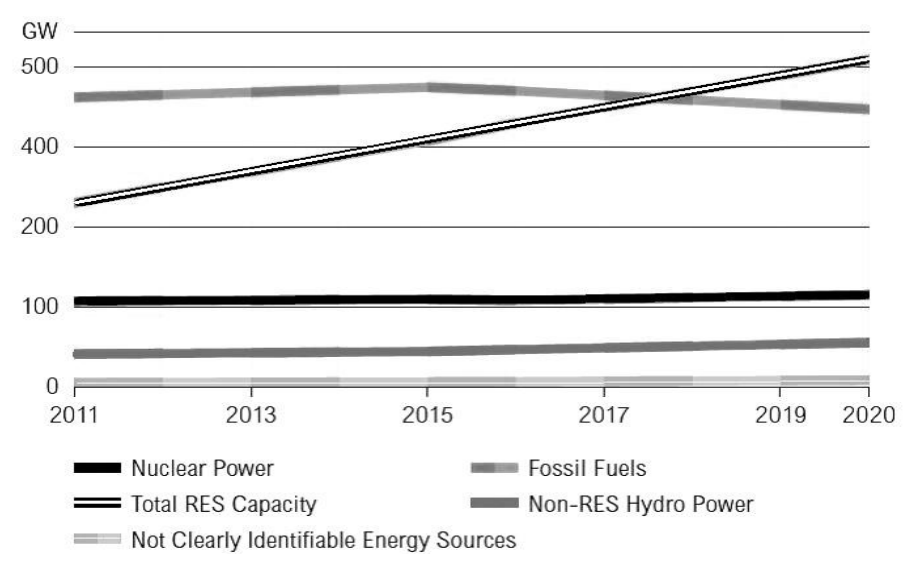

Fig.1. Net Generating Capacity breakdown in the EU 2020 Scenario by ENTSO-E.

Operation and development of a real PS is traditionally a non-interruptible process that cannot be replaced only by 1-3 development horizons in planning tasks. The relevant research should elucidate the capacity adequacy and the system reliability aspects for a future PS with high RES penetration [2].

The volume of electricity generation is different at differing operational states of a PS. In competitive markets this is driven by price differences, which sometimes can be significant in the system with high RES percent (Fig. 2). Different generating technologies provide flexible electricity by dissimilar ways: some can start up from the zero output and "ramp up" within seconds, other may take hours but can quickly flex their output up to meeting the PS needs. These slower technologies can meet the system's flexibility requirement of today; usually there can be combined cycle-gas turbine or coal-fired plants. On the other hand, older coal plants and especially gas-fuelled stations are unable anymore to cover their full costs given today's electricity market prices, and, consequently, cannot be 
operated on a commercially viable basis. Thus the inference is that the modern PSs require a sufficiently flexible capacity mix and its adequacy $[4,5]$.
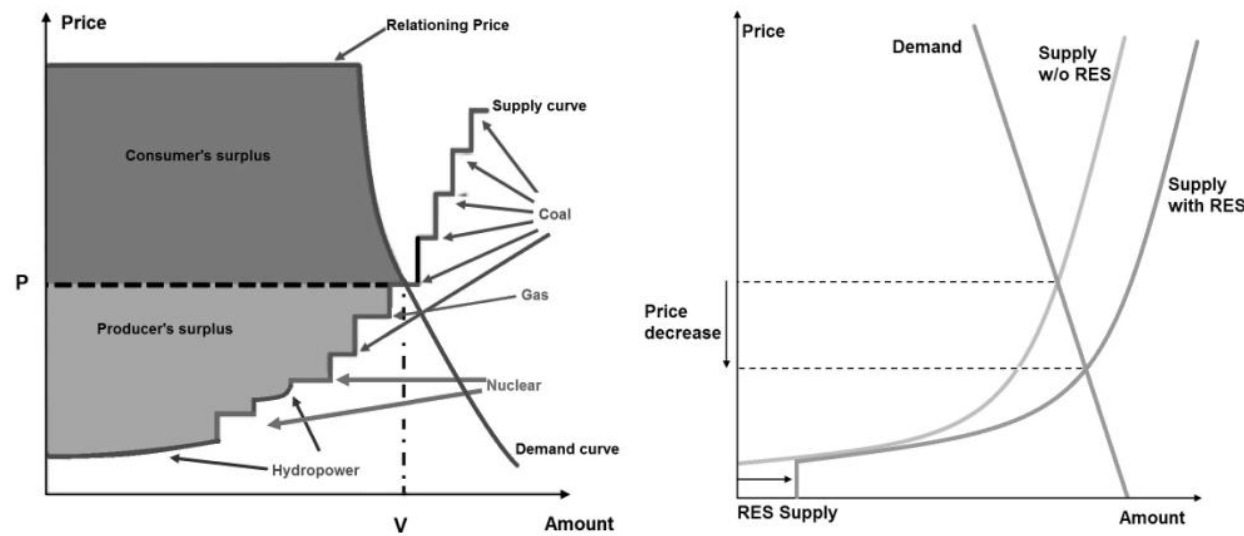

Fig. 2. RES impact on the power supply.

A significant factor in this issue is also the need for extra transmission and installation costs regarding new RES power production units. The renewable generation plants have to be sited at the places where the primary energy resources are located, and often cannot be sited closer to an existing transmission line or a load centre [3]. Therefore, the installation and transmission costs can be quite high, especially when the offshore wind power comes into play.

The long-term design and optimization of a power system should be driven taking into account the electricity market factors and PS characteristics at calculation of the relevant technical, reliability, economic and ecological criteria.

\section{COST ESTIMATION \\ FOR A GENERATING TECHNOLOGY}

Under the economic conditions such terms in the power production sector as the cost concepts and economic efficiency have become even weightier since the liberalization and market principles were introduced (Fig. 3). These terms are basic in assessment of the viability of investment projects concerning both the power generators and the network infrastructure. There is a direct relationship between the revenues and a plant's output - this latter being unreliable in the case of, e.g., wind generation. Stochastic nature of the wind implies its forecasting complexity; hence, hard-foreseeable variation in the output of such a power source might be expected $[6,7]$.

At the same time, the planning horizons for a system that has to withstand unfavourable impacts as well as significant seasonal and regional weather fluctuations are the facts that have to be taken into account while planning a technical infrastructure. This, especially in the energy sector, is realized in advance (from years to decades); moreover, being not dimensioned for the actual conditions due to the large, expensive and highly sophisticated sub-systems with relatively 
long life cycles. In addition, these sectors are in close co-operation, with relatively high level of mutual operational and economic influence.

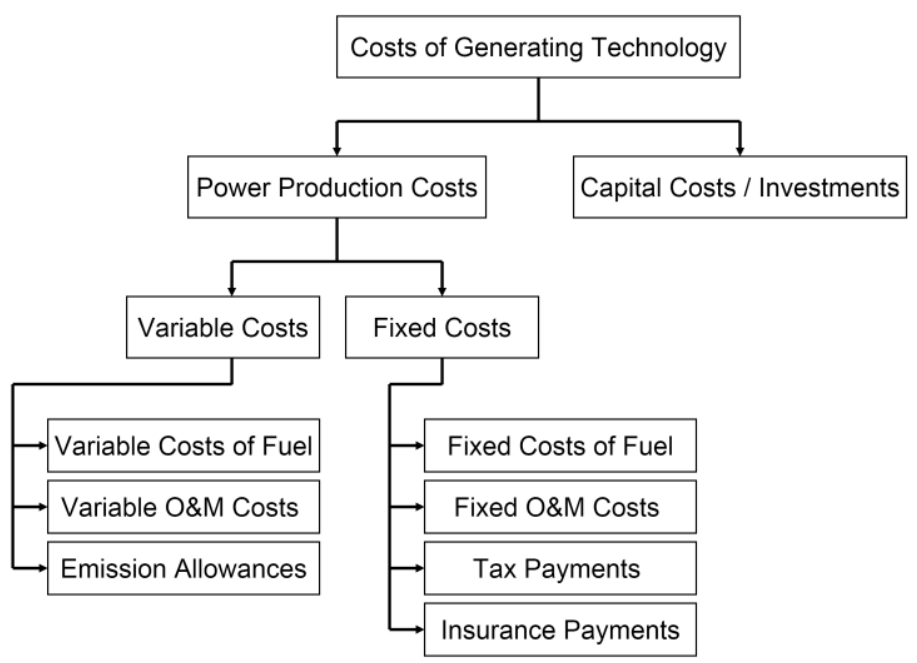

Fig. 3. Basic cost structure of a power generating technology.

Considering the annual revenue of the power plant based on the sold electricity and the power plant utilization, this could be formulated as TR (total revenue $)=A R R($ annual revenue requirement), i.e.:

$$
\begin{aligned}
& C_{e l} \cdot W_{s l}=C_{f i x}+C_{\mathrm{var}} \Rightarrow C_{e l}=\frac{C_{f i x}+C_{\mathrm{var}}}{W_{s l}} \\
& A R R=C_{f i x}+C_{f} \cdot C_{\mathrm{var}},
\end{aligned}
$$

where $C_{e l} \quad$ is the electricity price [m.u./MWh];

$W_{s l} \quad$ is the sold annual volume of electricity [MWh];

$C_{f} \quad$ is the annual capacity factor of power plant $[0 \rightarrow 1]$.

\section{COST CONCEPTS IN PLANNING AND OPERATION}

The most important cost concepts often applied in relevant assessments are:

a) short-run marginal cost concept (SRMC);

b) long-run marginal cost concept (LRMC);

c) levelized cost of electricity concept (LCOE).

\subsection{Short-run marginal cost concept}

The market-based price of produced electricity in the environment with perfect competition (assuming a pure cost of serving next MW of power) accounts only for a variable part of the total production cost. This short-run marginal cost 
(SRMC) is therefore not covering the fixed part of a power plant, which is on the spot markets covered by generator surplus. Such approach could cause in a longterm perspective the deficiency of revenues thus not covering all costs. Therefore, relevant mechanisms for treatment of these situations are proposed, e.g. capacity payments. Nevertheless, the SRMC concept seems to be the most appropriate to express the production unit behaviour in a competitive environment (i.e. with bids of producers). The short-run marginal cost of generating unit $(g)$, [€/MWh], can be described as

$$
S R M C_{g}=\{C_{v a r}+\overbrace{\frac{F_{c}}{\eta_{g}}+\frac{E_{x}}{\eta_{g}}}^{B}\}_{t},
$$

where $F_{c} \quad$ is the estimated price of the fuel used

$$
\text { in production unit }(g) \text {, [€/MWh]; }
$$

$\eta_{g} \quad$ is the efficiency of the power plant, [\%];

$C_{v a r}$ is the variable cost of production of the power plant, [€/MWh];

$E_{x} \quad$ is the external electricity production cost of used fuel, [ $\left.€ / \mathrm{MWh}\right]$.

In the case of a combustion unit this cost can be considered as the product of the emission tax and the emission per generated MWh with respect to the fuel used at this unit. However, as concerns the wind power production, part $B$ of formula (3) is equal to 0 , since no fuel and hence no external cost related to the fuel combustion is considered. Using the merit-order principle based on SRMC in the pool or exchange structure of the market, it is possible to simulate the resultant price that appears in the market being determined by a marginal generator or a discrimination auction.

\subsection{Long-run marginal cost concept}

The long-run marginal cost concept of generation is defined as the levelized cost of meeting the increased demand over an extended period of time. The LRMC is the wholesale price that should be earned by a generator, on average, in order to recover the capital and operating costs during year $(t)$. The LRMC of production can be determined by several ways.

From a long-term perspective, all factors of production are variable, and this conceptual period is appropriate for strategic decision-making as to changing the capacity level to reach the lowest cost associated with adding a production unit. Expressions of the LRMC concept for a production unit include the SRMC given above:

$$
L R M C_{g}^{t}=\left\{\frac{N_{c \& i}+N_{f i x}}{W_{a}}+S R M C_{g}\right\}_{t},
$$


where $L R M C_{g}$ is the long-run marginal cost of generating unit $(g)$,

[€/MWh] in year $(t)$;

$N_{c \& i} \quad$ is the discounted annual capital/investment cost

for unit $(g)$ and year $(t)$, [m.u.];

$N_{f i x} \quad$ is the annual fixed cost independent of unit $(g)$ operation in year $(t)$, [m.u.];

$W_{a} \quad$ is the total energy produced in year $(t),[\mathrm{MWh}]$.

From the perspective of decision-making on the generating capacity (a power plant) it is appropriate to compare the income (i.e. the revenue that the power plant is able to gain from the market) with its LRMC. Considering the situation when the income of a power plant is gained only from the wholesale spot market - i.e. the capacity payment, ancillary service provisions, etc. - the flowchart for assessment of the economic viability of a generating unit is shown in Fig. 4.

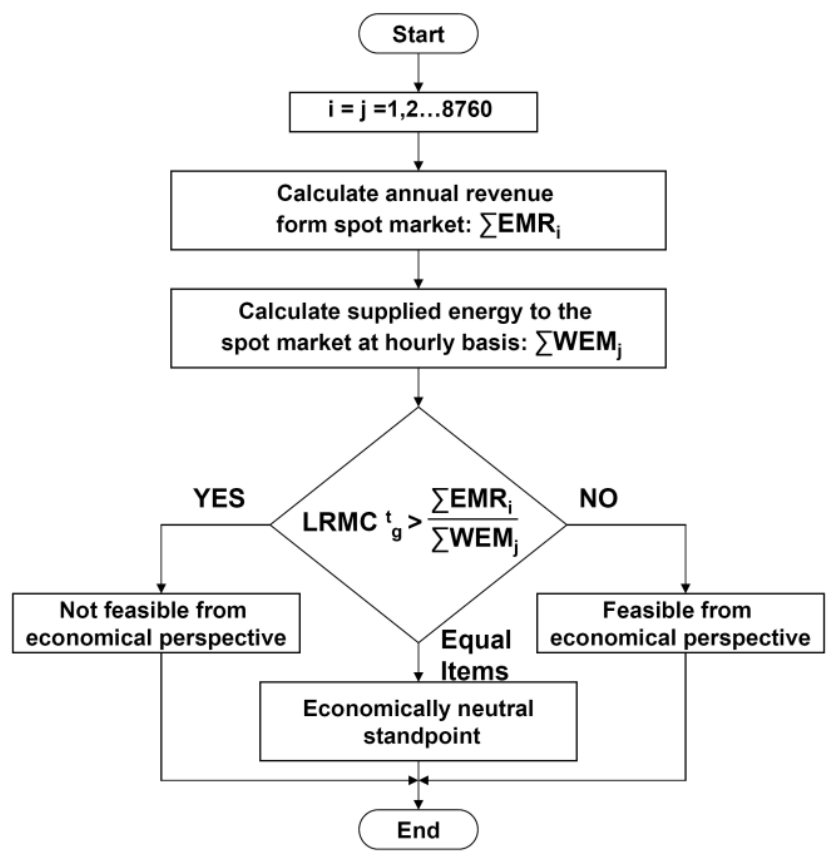

Fig. 4. Assessment of a power plant's economic viability.

\subsection{Concept of levelized cost of electricity}

The estimation of levelized cost of electricity is a tool for comparison of different type power production units over their economic life (mostly in the tasks of long-term planning and decision-making). The principle applied in LCOE calculations does not account for the risks associated with the liberalized competitive market environment because relies on the certainty of production costs and the stability of electricity prices. Therefore, real investments in a new 
generating capacity may differ from the calculated LCOE due to specific uncertainties of the market environment. The LCOE is usually calculated as

$$
\begin{aligned}
& \sum_{t}\left(\text { Electricity }_{t} \cdot P_{\text {Electricity }} \cdot(1+r)^{-t}\right)= \\
& \sum_{t}\left(\left(\text { Investment }_{t}+O \& M_{t}+\text { Fuel }_{t}+\text { Carbon }_{t}+\text { Decomissioning }_{t}\right) \cdot(1+r)^{-t}\right) \\
& P_{\text {Electricity }}=\frac{\sum_{t}\left(\left(\text { Investment }_{t}+O \& M_{t}+\text { Fuel }_{t}+\text { Carbon }_{t}+\text { Decomissioning }_{t}\right) \cdot(1+r)^{-t}\right)}{\sum_{t}\left(\text { Electricity }_{t} \cdot(1+r)^{-t}\right)} \\
& P_{\text {Electricity }}=\text { LCOE },
\end{aligned}
$$

where

$$
\begin{array}{ll}
\text { Electricity }_{t} & \text { - the amount of electricity produced in year }(t) ; \\
P_{\text {Electricity }} & \text { - the constant price of electricity; } \\
(1+r)^{-t} & \text { - the discount factor for year }(t) ; \\
\text { Investment }_{\text {Decomissiming }} & \text { - the investment costs in year }(t) ; \\
\text { O\&M } & \text { - the decommissioning cost in year }(t) ; \\
\text { Fuel }_{t} & \text { - the operation and maintenance costs in year }(t) ; \\
\text { Carbon }_{t} & \text { - the fuel costs in year }(t) \\
& \text { - the carbon dioxide emissions' costs in year }(t),
\end{array}
$$

Despite shortcomings of LCOE calculation, this remains the most transparent consensus technique for generation cost estimation and a widely used tool for comparative cost estimation of different generation technologies.

\section{LEVELIZED COSTS FOR DIFFERENT GENERATION TYPES. RESULTS AND DISCUSSION.}

The profitability investment estimation must rely on modelling, which requires knowledge of the future costs and revenues of the generation project and their variations.

The power plant's economic viability assessment and LCOE analysis are meant for identification of the investment risks in a power generation sector when choosing among the generating options, with different lead times' cost and uncertainties in order to compare the technologies with dissimilar characteristics [8-10].

Figure 5 shows the levelized costs of electricity production (LCOE) split into O\&M costs, fuel costs and $\mathrm{CO}_{2}$ costs. These last costs have been calculated based on the certificate price of $30 \mathrm{EUR} / \mathrm{t} \cdot \mathrm{CO}_{2}$, with the investment costs disregarded as the modern power market model works on the marginal pricing principle. 


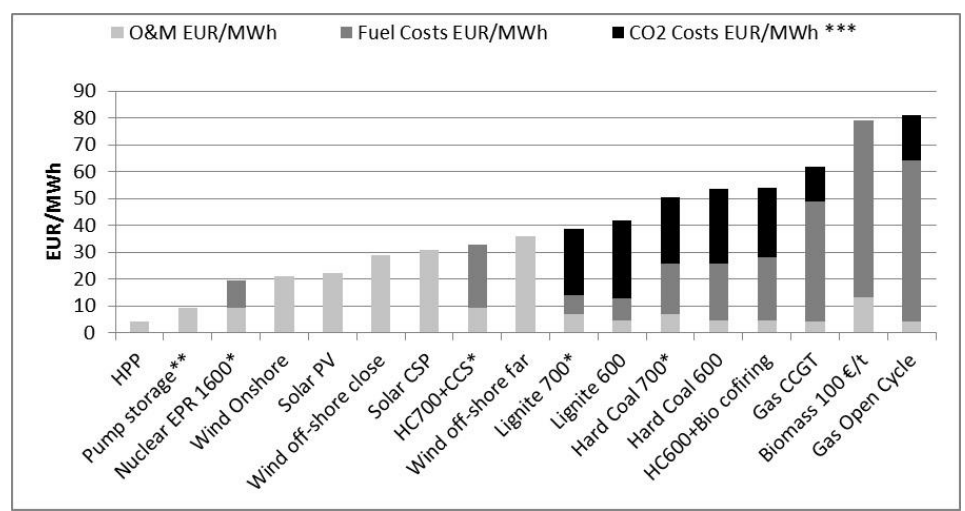

Fig. 5. Levelized costs of electricity for different generation types.

The LCOE estimation diagram in Fig. 5 shows that the generating units with the least marginal costs are hydro-power plants (HPPs) followed by all renewable and nuclear technologies. At the last place (with the highest marginal costs) is the gas open-cycle technology, which has the highest fuel and $\mathrm{CO}_{2}$ costs.

Analysis of the electricity production costs including the investment ones shows that the situation with the merit order of production technologies changes dramatically.

In Fig. 6 the total costs of electricity production are displayed including the investment costs. These latter have been calculated based on the equivalent annual cost method at a $10 \%$ discount rate. In the diagram it could be seen that the position of HPPs has not changed, while all the conventional technologies shifted to the beginning of the merit order owing to high investment costs of the renewable technologies.

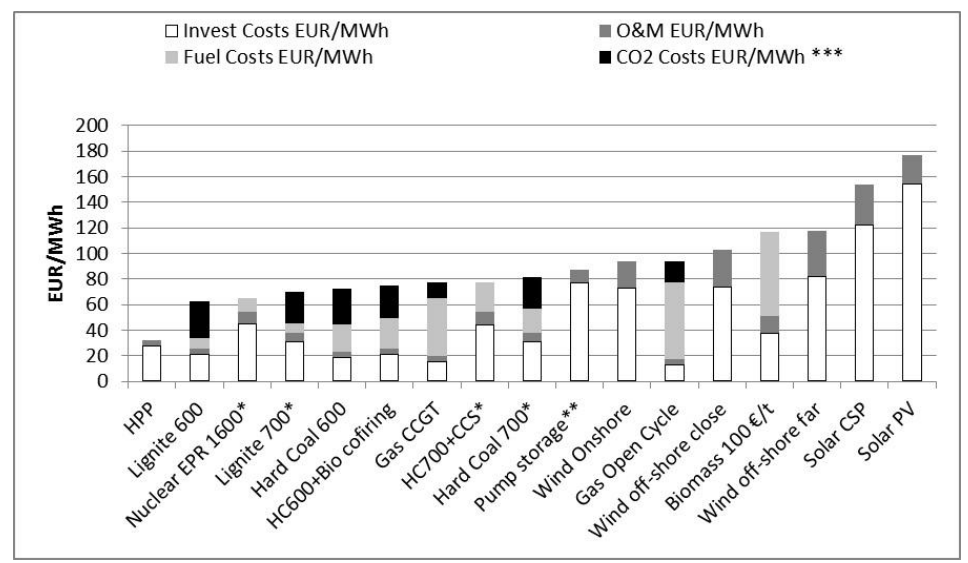

Fig.6. Estimation of electricity production costs including the investment costs.

This means that the renewable technologies can take a different place in the merit order as compared with conventional technologies including fuel and $\mathrm{CO}_{2}$ costs.

The figures mentioned above provide the order of magnitude which reveals the trends and comparative cost advantages of the most popular generation technologies of the major players in Europe for the time span up to 2030. 


\section{CONCLUSIONS AND FURTHER RESEARCH}

Research described in this paper is based on the analysis of the operation and development planning of a modern system, which requires a sufficiently flexible mix of generating capacities as well the right types of capacity with estimation of long-term perspectives. In practice, the generating plants give not a single output but a variety of outputs - kWh plus a set of other services such as reliable capacity, which can be brought together under the general heading of system support services. RESs are usually not dispatchable, and less capable of providing such type of support; in practice, they increase the need for support from the rest of the power system.

To solve strategic planning questions in this situation, the first step requires the creation of several real-value capacity scenarios with estimation of different mixes of technologies and development perspectives.

In the work, the Power Plant's Economical Viability Assessment and the Levelized Cost of Electricity concepts have been formulated and real technologies are analyzed.

The cost concepts of the power production sector are highly important for determination of the appropriate cross-border investment projects within the EU. This issue will become even more urgent and noticeable with introduction of the IEM target model.

\section{ACKNOWLEDGEMENTS}

This work supported by the European Social Fund project „Exploration and Solving of Energy Systems' Strategic Development and Management TechnicallyEconomic Problems", agreement No.2013/0011/1DP/1.1.1.2.0/13/APIA/VIAA/028.

\section{REFERENCES}

1. European Network of Transmission System Operators for Electricity (ENTSO-E) (2010). Scenario Outlook and System Adequacy Forecast 2011-2025, Brussels: ENTSO-E AISBL, p. 168.

2. Krishans, Z., Mutule, A., Merkuryev, Y., \& Oleinikova, I. (Jan. 2011). Dynamic Management of Sustainable Development - Methods for Large Technical Systems (1 ${ }^{\text {st }}$ ed-n). Springer, XXIII, ISBN: 978-0-85729-055-7, p. 190.

3. Keay, M. (Febr. 2013). Oxford Energy Comment, Renewable energy targets: the importance of system and resource costs. The Oxford Institute for Energy Studies.

4. OECD/IEA. Power Generation investment in electricity markets. (2003).France.

5. Rautkivi, M., \& Kruisdijk, M. (July-Aug. 2013). Europe's balancing act. Power Engineering International, 16-20.

6. Joskow, P. L. (June, 2012). Competitive electricity markets and investment in new generating capacity. MIT, p. 74.

7. Turcik, M., Oleinikova, I., Junghans, G., \& Kolcun, M. (2012). Methods for Estimation of Market Power in Electric Power Industry. Latv. J. Phys. Tech. Sci., (2), 14-22.

8. VGB Survey (2011). Investment and Operation Cost Figures: Generation Portfolio.

9. Sauhats, A., Vempers, G., Inde, J., \& Neimane, V. (July 2007). On co-eneration strategies in the cities of North-Eastern Europe. Power Tech., 07 IEEE , Lausanne (Switzerland), 645-650. 
10. Neimane, V., Sauhats, A., Vempers, G., Tereskina, I., \& Bočkarjova, G. (May, 2009). Allocation production cost at CHP Plant to Heat and Power based on Cooperative Game Theory. In: $6^{\text {th }}$ Intern. Conf. on the European Energy Market, Lèvene (Belgium), 182-187.

\title{
INVESTĪCIJU PLĀNOŠANA ELEKTROENERĢIJAS RAŽOŠANAS IEKĀRTĀS MŪSDIENAS TIRGŪ AR LIELO AER İPATSVARU
}

\author{
I. Oḷeininikova, O. Rukšāns, M. Turčik \\ Kopsavilkums
}

Mūsdienās energoinfrastruktūras attīstības un tā vadības procesā ir jāpieņem un jāpilda vairāki lēmumi par nepieciešamiem kapitālieguldījumiem, kas ir rūpīgi jāplāno un jāpamato. Viedo tīklu tehnoloǵiju ieviešana un energosistēmas drošuma uzturēšana, ņemot vērā liberalizēto elektroenerǵijas tirgu, rada nepieciešamību pēc principiāli jaunām pieejām un metodēm kapitālieguldījumu novērtēšanas uzdevumu risināšanai. Pētījums veltīts investīciju plānošanai elektroenerǵijas ǵenerācijas iekārtai elektroenerğijas tirgus apstākḷıs, ņemot vērā lielo atjaunīgo energoresursu (AER) ippatsvaru.

Modernu energosistēmu vadība prasa pietiekamu ǵenerācijas jaudas elastīgumu un to pareizo kombināciju. Lai to sasniegtu, vispirms ir nepieciešama dažāău ǵenerācijas tehnolog̣ijas izmaksu novērtěšana, ko var veikt, izmantojot pienācīgo instrumentu. Tas arī ir pētījuma mērḳis, kura rezultātā tika piedāvāta elektrostaciju ekonomiskas dzīvotspējas novērtēšanas koncepcija, balstoties uz elektroenerǵijas ražošanas līmeņizmaksām (ed costs), lai salīdzinātu dažādu elektroenerǵijas ražošanas tehnolog̣ijas izmaksas.

Lai to sasniegtu tika veikti:

> investīciju plānošana ǵenerācijā, metožu pētīšana;

$>$ elektrostaciju darbības principu analīze elektroenerğijas tirgū;

elektrostaciju ǵenerācijas tehnologijas izmaksu novērtēšana;

$>$ elektrostaciju ǵenerācijas īstermiņa un ilgtermiņa izmaksu novērtēšana;

> elektrostaciju ǵenerācijas investīciju un vadības izmaksu novērtēšana;

$>$ dažādu ǵenerācijas tehnoloǵiju izmaksu skaitliskie aprēķini un analīze.

Īpaša uzmanība veltīta investīciju plānošanai elektroenerǵijas ražošanas nozarē liberalizēta tirgus apstākḷos; tika izanalizēti efektīvie instrumenti, izmaksu metodes un ekonomiskās efektivitātes novērtēšanas nozīme dažāda tipa ǵenerējošām jaudām un tās atbilstība mūsdienu elektroapgādes sistēmas prasībām.

25.10.2013. 